\title{
sciendo
}

CIVIL AND ENVIRONMENTAL ENGINEERING REPORTS

E-ISSN 2450-8594

CEER 2020; 30 (2): 0234-0246

DOI: $10.2478 /$ ceer-2020-0029

Original Research Article

\section{THE INFLUENCE OF ECOPHYSIOGRAPHIC DETERMINANTS ON THE FUNCTIONAL-SPATIAL DEVELOPMENT OF RURAL AREAS - A STUDY OF THE VILLAGE OF LUBASZ}

\author{
Hanna BORUCIŃSKA - BIEŃKOWSKA ${ }^{1}$ \\ ${ }^{1}$ Faculty of Civil Engineering, Architecture and Environmental Engineering, Department \\ of Architecture and Urban Planning, University of Zielona Gora, Poland
}

\begin{abstract}
The article discusses selected issues concerning the influence of ecophysiographic determinants on functional-spatial and socio-economic development in rural areas. Ecological, economic and social processes that have been taking place for the past few decades are examined in the context of the development of local self-governments and transformation of economic processes into market oriented economy following socioeconomic changes in Poland. The process of intense urbanization of the countryside is a common phenomenon that occurs specifically in rural areas that are within the impact zone of a big city. It is caused by i.a. human migration into rural areas as well as by development of areas of business activation. These tendencies, which occur both in the social and economic context, greatly affect ecological processes. Expansion of land development and the ensuing further development of necessary technical infrastructure give rise to numerous problems in natural environment. Ecophysiographic determinants play a vital role in the pursuit of sustainable development of the countryside in the aspect of threats that result from excessive urbanization of rural areas. The author discusses these issues on the example of a study of the village of Lubasz in the wielkopolskie voivodeship.
\end{abstract}

Keywords: economic, ecological and social processes, ecophysiography

\footnotetext{
${ }^{1}$ Corresponding author: Faculty of Civil Engineering, Architecture and Environmental Engineering, University of Zielona Gora, ul. Szafrana 1, 65-516 Zielona Góra, Poland, h.borucinska-bienkowska@aiu.uz.zgora.pl
} 


\section{INTRODUCTION}

Transformation of rural areas in Poland occurs at different paces and on a variable scale, and is a result of i.a. factors that arise from historical borders (mainly the borders of the partitioned Poland, as well as border-shifts after World War II) as well as their location in relation to a big city. The post-war period is special in terms of migration of young people entering the job market in big cities. Eberhardt says [4] that the effects of an outflow of people from rural areas to cities, which contributed to the urbanization process, occur at many levels. They not only take the form of rural depopulation, but they can be also observed as disruptions of socio-demographic structures (of gender and age). In the last three decades, the outflow of people from rural areas to cities, which are centres of industrial development, has transformed into economic migration abroad. Along with the socio-economic development of Poland, the trend has considerably decreased, and the countryside, especially the areas located within the impact zone of a big city, have become attractive for housing development and business activation.

Wiklina and Nurzyńska are co-authors of a report on the state of the countryside, published in 2016 [19]. The report reveals that $10 \%$ of countryside dwellers have jobs based on agriculture. The process will be constantly changing because agriculture in Poland is a source of income for the highest percentage of population in comparison to analogous data on Western European countries. The employment index for agriculture is permanently dropping. After 1989, rural areas, especially those located within the impact zone of big cities, registered a reverse process of rural depopulation. It is influenced by i.a. the suburbanization process occurring in metropolitan areas. The human migration is triggered by ecological, economic and social determinants and factors. The most crucial role in the process is played by social (related to i.a. characteristics specific to local communities) as well as economic determinants and factors (related i.a. to dynamic economic development of rural communes bordering a big city).

Bański [3] writes that determination of typology for the classification of contemporary rural areas depends on the applied methodology. Three categories can be distinguished, i.e. related to localization, structure and combination. The location category results from the concept of urban-rural continuum, and it renders it possible to define cities, their impact zones, and villages. The structural methodology analyses a set of socio-economic determinants and factors in such a way as to classify areas according to their functions. The combination method, as the name suggests, combines the two methods discussed above. We can classify and describe examined rural areas depending on the assumed method. However, irrespective of the above-mentioned variants, ecological, economic, and social determinants and factors also exert an impact 
on rural transformation. These include i.a.: economic development, modernization, extension and construction of technical infrastructure, including a network for transportation of people and vehicles. Other experts, Kłodziński [10], Koreleski [12], Adamowicz [1] highlight the multifunctional nature of rural areas as a factor ensuring their sustainable development. Rural areas, especially those that boast attractive environmental, tourist and cultural values, are currently undergoing an influx of people of non-agricultural occupations for housing reasons. The ongoing socio-economic transformation, easy access to new technologies and job markets, the need of a change of scene and lifestyle also influence the settlement processes that accompany city dwellers moving into rural areas. The economic and social transformations have contributed to further urbanization of rural areas, which has a vital impact on environmentalgeographical conditions.

Specialists claim that analyses carried out in various rural areas in Poland enable determination of specific selected model situations of cooperation in reference to sustainable development, as well as integration of migrants with local communities. The issue is discussed i.a. by Bański [2, 3], Eberhard [4], Heffner and Klemens [5], Kiełczewska-Zaleska [9]. Settlement networks of rural areas undergo dynamic changes, which are greatly influenced by economic conditions, such as i.a. attractive prices of investment plots, access to technical infrastructure, as well as a transport network for people and vehicles at the local and supralocal levels. The transformation process of the countryside has been taking place for over three decades with variable intensity, and it can be assumed that it will continue in the future. The perspective of the incoming years predicts strengthening the role of social and economic determinants and factors, but the dynamic and excessive sprawl compounds problems related to ecology; natural geographical environment also comes under threat. These issues are presented i.a. by Heffner and Klemens [7]. The authors draw attention to the fact that uncontrolled functional-spatial development may cause environmental-spatial conflicts. Current provisions of studies of spatial planning conditions and directions as well as of local spatial management plans provide for an excessive number of areas designated for housing functions, business activation and for multi-purpose needs. Without suitable analyses of determinants and factors in the ecological, economic and special context, wrong decisions may cause unwanted or even harmful effects on the geographical-environmental and cultural habitat. Negative economic effects are discussed in [13], published in 2013. The authors highlight the costs related to modernization, extension and construction of technical infrastructure, including transport networks for people and vehicles. Another problem is access to basic and secondary services. In his work [7], Kajdanek presents the issue of access to basic services within walking distance in rural areas which have transformed into expanding single-family 
housing estates in the last decades. Urbanization of rural areas is also caused by accessibility of investment areas. Obviously, modernization, extension and construction of technical infrastructure and a generally understood technological development is a positive phenomenon, but, paradoxically, the same standards of living in the city and in the countryside boost attractiveness and extension of housing areas in the latter. This, in turn, leads to excessive degradation of the natural environment, including the rural landscape. Villages are becoming home to non-agricultural residents; many occupations are completely transformed also in the scope of spatial order. New residents bring in not only culturally alien housing forms but also different forms of shaping the rural landscape. New residences are surrounded by gardens of various styles that fail to refer to local traditions, and destroy local fauna and flora. Tight fencing or hedges disable migration of plants and animals; ecological corridors are broken. New functional-spatial development is carried out on an intensive complex scale. Former agricultural lands are covered by a regular grid street plan with tiny plots.

\section{CURRENT GEORGAPHIC - ENVIRONMENTAL CHARACTERISTICS OF THE HABITAT. CASE STUDY - THE VILLAGE OF LUBASZ}

The selected issues addressed in the introduction are analysed based on the factors and determinants occurring in the village of Lubasz. In the study of the conditions and directions of spatial development of the Lubasz commune that was approved by the Resolution of the Commune Council no. IV/38/19, 25 February, 2019, in the village of Lubasz an area similar in size to the present inhabited area of the village has been designated for human habitation.

In the author's opinion, excessive urbanization may pose a threat to the correct functioning of a geographic-environmental habitat. This is where, i.a., the study of the above-mentioned habitat originates, and so does analysis of ecological determinants that are in close relation to determinants of economic and social nature.

As an insight in the discussion on the functional-spatial transformation of rural areas, this paper addresses selected issues concerning determinants and factors that have a considerable impact on the ongoing changes. The positive and negative effects of the above-mentioned actions will depend on the pace and scale of these transformations, on awareness of the local self-government and local community, as well as on the pursuit of sustainable development of the village of Lubasz.

Rapid economic, socio-demographic and functional-spatial changes render rural areas an attractive place for city-dwellers to inhabit. 


\section{SELECTED ECOLOGICAL CONDITIONS}

\subsection{Geographical location and climate}

The village of Lubasz is located in the Lubasz commune (commune area: 167.7 $\mathrm{km}^{2}$ ), Czarnków-Trzcianka poviat, in the north-west part of the wielkopolskie voivodeship [1]. The village located in the north-eastern part of the commune on the edge of the moraine range is its administrative centre. In 2018 Jerzy Solon, Andrzej Richling, Wiesław Ziaja et al. published a modified version of the division of Poland into physico-geographical regions in the journal Geographia Polonica. The new division is a modification of the division by Kondracki and Richling from 1994. It was made in 1:50,000 detail, and the boundaries of mesoregions were determined using the latest data and their analyses in GIS systems. The village of Lubasz lies within the macroregion of Pojezierze Wielkopolskie (315.5) and in the mesoregion of Pojezierze Chodzieskie (315.53), as well as partly in the macroregion of the Torun-Eberswald Stream valley (315.3) and in the mesoregion of Kotlina Gorzowska. According to Bogumił Krygowski [map 1], the village of Lubasz lies in the region of the Torun-Eberswald Stream Valley and the subregion of Kotlina Gorzowska as well as in the region of Wysoczyzna Gnieźnieńska and the subregion of Pagórki Czarnkowskie.

The above-mentioned village has a varied terrain that influenced the processes related to the disappearance of glaciation. The north-east part of the village is the highest. The terrain decreases to the south and west of the river valleys. The majority of the village is within the moraine plateau.

The climate of the village is characterised by oceanic and continental influences with a large number of cloudy days and the lowest amount of rainfall in Poland. Climatic conditions are analogous to those for the above-mentioned subregion:

- the average annual temperature is $7.5^{\circ} \mathrm{C}$,

- the average temperature in July is $18^{\circ} \mathrm{C}$,

- the average temperature in January is $-1.7^{\circ} \mathrm{C}$,

- the number of cloudy days is about 155 ,

- the vegetation period lasts about 210 days,

- the average annual rainfall is $450-500 \mathrm{~mm}$

- winds mostly from the west and south-west.

The climate of the village is significantly affected by a large forest complex located in the southwestern part of the commune, as well as park and cemetery greenery. The forest causes, among others, night temperature drops (reduction of daily air temperature amplitudes), weakening of the strength of blowing winds, higher rainfall, higher humidity. The proximity of the Noteć river valley, Duże lake and numerous watercourses affect the frequency and scale of fog 
occurrence. The terrain also has a great impact on the microclimate. The topoclimates present in the area are:

- wooded areas

- flat field areas - agricultural land with average climatic conditions,

- flat areas of arable land and meadows with shallow groundwater,

- urbanised areas with anthropopressure,

- arranged green areas (beneficial for the natural environment).

During frosty and cloudless nights there is a phenomenon of shifting masses of cool air from higher areas towards river valleys - the valley of the Gulczanka river, the Lubaski canal, to watercourses and wet meadows.

\subsection{Geomorphology, surface shape}

The shape of the terrain of the studied village was influenced by both processes related to the outflow of water from the face of the glacier and subsequent weather and climate processes, including climate warming and rising waters.

Towards the south-west, i.e. towards the river valleys, the area is lowering. The north-east part of the village of Lubasz was formed during the Czarnków oscillation and is located within the frontal moraine.

The highest elevated area of the village is $103.5 \mathrm{~m}$ above sea level, the lowest is $76.5 \mathrm{~m}$ above sea level. Deleveling in the village is from 5 to $27 \mathrm{~m}$, and the decline in the north-eastern region is up to $20 \%$. The village is located within the moraine plateau, which for the most part is a bottom moraine. The varied terrain is primarily the result of ice sheet accumulation, erosive and accumulative water activity, outflow of water in the foreland of the ice sheet and wind activity. Such terrain has a significant impact on the functional and spatial development of the village, determining the forms of buildings.

There are no natural geological hazards in the village of Lubasz, which is important for sustainable functional and spatial development.

\subsection{Soil and water conditions}

Groundwater occurs at various depths. It depends on the geological structure and arrangement of the impermeable layers. Utility groundwater occurring in the commune is associated with the Quaternary and Tertiary aquifers. Aquifers occur at a great depth and are covered with layers that isolate water against the penetration of dirt. The average depth of the water intake is $100 \mathrm{~m}$.

There are several levels of groundwater in the village of Lubasz. The first level includes river valleys and lake gutters and drainage depressions.

The village is located entirely in the basin of the Warta river. The largest lake of the commune is Duże, 41.44 ha, volume about 2092.4 thousand $\mathrm{m}^{3}$ and an average depth of 5.0 (maximum depth of $11.4 \mathrm{~m}$ ) partly located in the northeastern part of the village of Lubasz. The lake has an elongated shape directed at 
east-west. Most of the lake's bank passes into steep slopes covered with trees and bushes. Duże lake borders the forest to the north and agricultural land to the south. A watercourse flows out of the lake. There are no areas exposed to flooding in the village.

Soil types and classes are another important condition for development. They reflect the geomorphological and natural conditions of the studied area. In the village of Lubasz there are varied soils in most parts of classes II, IIIa and IIIb suitable for arable crops.

\subsection{Flora and fauna as well as forms of nature protection}

The vegetation of the village of Lubasz is dominated by large forest complexes. They constitute a natural and unquestionable natural potential. Due to the sandy ground, pine is the dominant species among the trees. Oaks and birches predominate among deciduous trees, other present species are alder, beech and ash tree. In the forest area of Lubasz - Krucz Forest District there are waterproofing forests. Under the Act [8], all forests are subject to protection consisting inter alia in:

- limiting their use for non-forest and non-agricultural purposes,

- preventing degradation and devastation processes,

- restoring the value in use of forest land that has lost its forest character through inter alia afforestation,

- improving the value and condition of biodiversity,

- improving their value in use.

The high values of the natural environment have resulted in the establishment of legally protected areas in the Lubasz commune. The largest are the "Puszcza Notecka" and "Dolina Noteci" Protected Landscape Areas. "Puszcza Notecka" covers the central and southern parts of the village. The entire above-mentioned area is an important element in the ecological system of international importance on a European scale. It connects the valleys of Noteć and Warta creating an ecological corridor. The area of the forest is hilly, consisting, among others, from dune sands. There are numerous species of birds, including herons, ospreys and white-tailed eagles on its territory.

"Dolina Noteci" consists of arable lands, forests of the Czarnków moraine, Duże lake and the Lubaski canal, as well as the arable land, meadows and grasslands bordering the above-mentioned areas. The above-mentioned area is an important refuge for birds and their migration route. It is characterized by a meadow-fieldsettlement landscape.

Protected landscape areas that are of significant natural value are a barrier to the development of rural housing functions. 
Elements of the plant cover are grasslands along the watercourses: the Gulczanka and Lubaska Struga rivers and the Lubaski canal.

Natural resources and landscape values are an important value of the village. They determine the scale and pace of development of housing functions. They constitute important conditions for the development of tourist, recreational and sport functions.

The village's natural resources also include meadows and pastures in the river valleys and watercourses. Habitats of many plant and animal species occurring in their areas create biodiversity.

A 30.7 ha historic park preserved in the village with old trees of oaks, poplars, ash trees and larches is an important element of the natural landscape. The park includes, among others, 28 trees that are protected natural monuments.

The above-mentioned areas with rich and diverse flora also have rich and diverse fauna.

The importance of backyard greenery, which performs utility functions (flower, vegetable gardens, orchards, etc.), recreational, decorative, and protective, as well as isolating greenery, should also be emphasized.

In the village of Lubasz there is an ecological site with an area of 1.1 ha located in a forest clearing on Duże lake.

Pursuant to the Act [8], agricultural land constituting arable land is also protected:

- classes I-III if their compact area planned for changing the purpose exceeds 0.5 ha,

- class IV if their compact area planned for changing purpose exceeds 1.0 ha,

- classes V and VI if their compact area planned for changing purpose exceeds 1.0 ha.

Agricultural land is subject to protection consisting, inter alia, in:

- limiting their use for non-agricultural and non-forest purposes,

- preventing degradation and devastation processes,

- restoring utility value to agricultural land that has lost its agricultural character,

- land reclamation and development for agricultural purposes,

- conservation of peat bogs, ponds,

- preservation of existing and introduction of new mid-field stands.

In the village of Lubasz, the historic manor park with an area of 30.7 ha, the Catholic church cemetery and the Jewish cemetery are also protected. Pursuant to applicable legal regulations and ecological awareness of the local community and local governments, it is necessary to protect all elements covered by legal protection and the entire natural environment. 


\section{QUALITY OF THE ENVIRONMENT - OPPORTUNITIES AND THREATS}

Various forms of nature protection, pro-ecological awareness of local communities and local authorities significantly affect the quality of the natural environment. Protected landscape areas include areas of outstanding fauna and flora, areas valuable due to biodiversity forming ecological corridors of local and supra-local, national and international range. In the village of Lubasz, all elements of animate and inanimate nature should be protected, with particular emphasis on nature monuments and Protected Landscape Areas. The richness of the natural environment, its good condition as well as its location and accessibility influence the development of recreational, sport and tourist functions of the abovementioned area.

The basic functions of the village of Lubasz include: housing, services with the majority of basic services, agricultural and forestry function, as well as recreational and sport function. The village of Lubasz is characterised by low investment in areas of economic activation (industrial, transport and storage), which affects the optimisation of threats arising from the above-mentioned activity.

Threats resulting from air pollution intensify in the autumn and winter and are the result of the emission of pollutants from local, individual boiler houses heating housing. There were no exceedances of permitted air pollution standards in the village of Lubasz. Compact forest and park greenery affect the cleanliness of air in the village.

Voivodeship road no 184 runs through the village of Lubasz. There are increased combustion emissions and noise around the road. Periodically, the quality of the air is affected by the sewage treatment plant, sewage catchment station, landfill, and animal husbandry The main nuisance concerns smells. They can ne counteracted by introducing strips of insulation green - trees and bushes.

\section{EVALUATION OF THE STATUS OF THE GEOGRAPHICAL AND NATURAL ENVIRONMENT}

The area of the Lubasz village has significant natural values, partly protected by law. This condition contributes to the good condition of the geographical and natural environment. Most of the natural and landscape values have retained their natural character. The greenery in historic parks and cemeteries looks good. The area covered by the survey is located within the Tertiary Main Groundwater Reservoir - the Złotów-Strzelce Krajeńskie sub-reservoir. The above-mentioned reservoir is insulated with several dozen meters of Quaternary sediments, which significantly limits the possibility of water contamination. 
Surface waters of Duże lake and the Gulczanka river as well as the first level of surface waters are most exposed to degradation. An important factor influencing the natural environment of the village is its socio-economic development. Growth of invested areas, development of housing construction and related extension of technical infrastructure, including communication and road connections.

\section{FORECAST OF CHANGES IN THE GEOGRAPHICAL AND NATURAL ENVIRONMENT}

In the village of Lubasz there is a lake of the 1st cleanliness class, a holiday centre with a camping site and summer houses, which, among others, form the basis for the development of recreational and tourist services in the village. Legal protection of significant natural areas shows the aspiration of local authorities and local communities to preserve the heritage of the natural environment. However, functional and spatial development of urbanized areas makes it necessary to strive for sustainable rural development. Attractive natural environment, Protected Landscape Areas, well-preserved rural layouts and historical facilities form an integrated offer for the development of recreational and sports services for both residents and tourists.

Anthropopression is another important factor affecting the natural environment. Striving for sustainable functional and spatial development of the village will allow to preserve the natural heritage and natural environment in good condition for future generations.

\section{SUMMARY}

In the village of Lubasz located in the commune of Lubasz in the north-western part of the wielkopolskie voivodeship there are protected landscape areas and numerous nature monuments. "Puszcza Notecka" covers the central and southern parts of the village. The above-mentioned area is an important element in the ecological system of international importance. It connects the valleys of Noteć and Warta creating ecological corridors.

Arable land, Czarnków moraine forests, Duże lake and the Lubaski canal can be found in the "Dolina Noteci" area. The above-mentioned area is an important refuge for birds and their migration route.

The village of Lubasz has historical rural layouts. The former functional and spatial arrangements have survived, including the palace and park complex with a Classicist palace. 
Functional and spatial development occurring in the village does not pose a threat to the natural environment. The above-mentioned do not emit into the atmosphere substances that exceed the permissible standards.

In the area of Duże lake the area lowers, creating wetlands and marshes with vegetation characteristic of this type of habitat. The lake and swamps are fed with watercourses, rainwater and snowmelt, which carry surface pollution, including from semi-arable lands.

Aquifers occur at a great depth and are covered with layers that isolate water against the penetration of dirt. The average depth of the water intake is $100 \mathrm{~m}$.

\section{CONSLUSIONS}

The directions of functional-spatial development of rural areas is influenced by ecological, economic, social, endogenous and exogenous factors. The functional-spatial development of the countryside should be carried out through protecting crucial characteristics and improving the natural environment as well as agricultural production area.

The paper addresses selected issues that have an impact on the functional-spatial transformation of the countryside. Both suburbanization and the rapid economic growth are testimony to the radical functional-spatial change that is under way in the rural areas. This new quality of urbanization highlights ecological problems in shaping the culture innate to a specific place and space of rural areas.

1. The principle of sustainable functional and spatial development should be followed in the design of new functions in rural areas. Particular attention should be paid to ecological conditions, while taking into account economic and social conditions.

2. Existing and planned use of land primarily requires:

2.1. preservation of existing areas under legal protection, with particular emphasis put on the Protected Landscape Areas, high quality agricultural land, compact forest complexes, Natura 2000 areas,

2.2. introducing revitalization, renovation and modernisation projects in the required scope for areas and objects of cultural and historical significance,

2.3. equipping all areas invested in appropriate technical infrastructure,

2.4. introducing environmentally friendly, low-emission heating sources for all users, to be used in practice in rural renewable energy

2.5. restrictions on the location of economic activation areas and production and service facilities,

2.6. guaranteeing proper waste management, with particular emphasis on waste resulting from business operations, 
2.7. reclaiming all areas requiring this process,

2.8. preservation of existing watercourses and water reservoirs.

\section{REFERENCES}

1. Adamowicz, M 2000. Wielofunkcyjne gospodarstwa rolne jako podmiot w rozwoju wsi i rolnictwa, [w:] Wiejskie gospodarstw domowe w obliczu problemów transformacji, integracji $i$ globalizacji. Prace Naukowe KPAiM, nr 33, Wydawnictwo SGGW, Warszawa.

2. Bański, J 2011. Wieś $w$ badaniach geograficznych - ewolucja badań $i$ przeglad koncepcji obszaru wiejskiego, [w:] Wieś jako przedmiot badań naukowych. EUROREG, Wydawnictwo Naukowe Scholar, Warszawa.

3. Bański, J 2014.Wspótczesne typologie obszarów wiejskich $w$ Polsce przeglad podejść metodologicznych. Przegląd Geograficzny, z. 4, Warszawa.

4. Eberhard, P 1989. Regiony wyludniajace się w Polsce. Prace geograficzne IG i PZ PAN, nr 148, Ossolineum, Wrocław.

5. Heffner, $\mathrm{K}$ and Klemens, B 2013. Koncepcje zmian i procesy przestrzenne $n a$ obszarach wiejskich $w$ Polsce. Prace Naukowe Uniwersytetu Ekonomicznego we Wrocławiu, nr 296, Wrocław.

6. Łęcki, W 2004 [Red.]. Wielkopolska nasza kraina. Wydawnictwo S.A. Kurpisz, Poznań.

7. Kajdanek, K 2011. Pomiędzy miastem a wsia. Wydawnictwo Nomos, Kraków.

8. Karwacka, G, Kijowska, J, Kijowski, A and Żynda, S 2006. Komentarz do map sozologicznych - arkusz Rosko, Obrzycko, Czarnków, Wronki. UAM, Poznań.

9. Kiełczewska-Zaleska, M 1972. Geografia osadnicza. PWN, Warszawa.

10. Kłodziński, M 1996. Wielofunkcyjny rozwój terenów wiejskich $w$ Polsce i w krajach Unii Europejskiej. Wydawnictwo SGGW, Warszawa.

11. Kondracki, J 1994. Geografia Polski. Mezoregion fizyczno-geograficzny. PWN, Warszawa.

12. Koreleski, K 1998. Rozwój wielofunkcyjny jako koncepcja aktywizacji gospodarczej wsi i rolnictwa. Zeszyt Nakowy AR, z. 59, Kraków.

13. Kowalewski, A, Mordasiewicz, J, Osiatyński, J, Stepień, J and Śleszyński, P 2013. Rapotr o ekonomicznych skutkach $i$ społcznych kosztach niekontrolowanej urbanizacji w Polsce. IZiPZ PAN, Fundacja Rozwoju Demokracji Lokalnej, Warszawa.

14. Kożuchowski, K 2005. Walory przyrodnicze w turystyce i rekreacji. Wydawnictwo Kurpisz, Poznań. 
15. Starkel, L 1991 [Red.]. Geografia Polski. Środowisko Przyrodnicze, PWN, Warszawa.

16. Studium uwarunkowań i kierunków zagospodarowania przestrzennego gminy Lubasz zatwierdzone Uchwałą Rady Gminy Lubasz nr IV/38/19 z dnia 25 lutego 2019.

17. Ustawa $\mathrm{z}$ dnia 16 kwietnia 2004 r. o ochronie przyrody Dz.U. Nr 92 z 2004 poz.880.

18. Ustawa z dnia 3 lutego 1995 r. o ochronie gruntów rolnych i leśnych Dz. U. $\mathrm{Nr} 16$ z 1995 r. poz. 78.

19. Wiklina, J and Nurzyńska, I 2016. Polska wieś 2016. Raport o stanie wsi. Wydawnictwo naukowe Scholar, Warszawa.

20. Wojewódzki Konserwator Przyrody, Rejestr pomników przyrody, www.poznan.pl (10.01.2020 r).

\section{MAPS:}

1. geomorphological division of Nizina Wielkopolska - by Krygowski B.

2. topographic maps - scale 1: 50,000, Rosko, Obrzycko, Czarnków, Wronki sheet,

3. hydrographic maps - scale 1: 50000, Rosko, Obrzycko, Czarnków, Wronki sheet,

4. zozological maps - scale 1: 50000, Rosko, Obrzycko, Czarnków, Wronki sheet,

Editor received the manuscript: 12.02 .2020 